\section{2th Annual APSA Teaching and Learning Conference Held in Washington, DC}

\author{
Heidi Souerwine, Director of Meetings and Conferences \\ Amanda Meyers, APSA Academic and Professional Programs
}

$\mathrm{T}$ he 12th Annual APSA Teaching and Learning Conference focused on the challenges and opportunities of teaching in the digital age where information literacy is a critical skill and all of us are "plugged in." This year's program committee, led by Mark Johnson, Minnesota State Community and Technical College, organized a dynamic program of sessions and workshops around the theme "Innovations and Expectations for Teaching in the Digital Era." Panels-organized in 12 content tracks and dedicated professional development workshop time slots-presented research on pedagogy and discussed best practices for engaging students and training them to think critically and write effectively as well as evaluate, consume, and generate knowledge of political science successfully, integrating digital techniques and traditional methods.

The program opened with the Keynote Address presented by John M. Sides of The George Washington University. Sides spoke on the challenges of communicating the results of political science research in a public sphere overstimulated by information. Teaching, Sides argued, is essential to bridging the public engagement gap between discipline. reluctant academics and lay persons who are interested in politics but not initiated to the norms of the profession. Political scientists, and especially political science educators, must be able to nimbly apply a large body of knowledge to current events in order to make it relevant to their students; refrain from relying on academic jargon without compromising the quality of the conclusions; and present their points as clearly and succinctly as possible. Sides also suggested that public engagement is becoming imperative for political scientists, and should be recognized as a valuable form of service to the

The presentation of the CQ Press Award for Teaching Innovation concluded the opening plenary. The award recognizes a political scientist who has developed an effective new approach to teaching in political science and carries a $\$ 500$ prize, sponsored by CQ Press. APSA is pleased to congratulate the 2015 award recipient, Victor Asal of the University at Albany, SUNY. Asal is recognized widely by his colleagues for his innovative teaching practices, most particularly for his development of classroom simulations. Both his scholarship on teaching and learning and its practice in his classroom qualified him

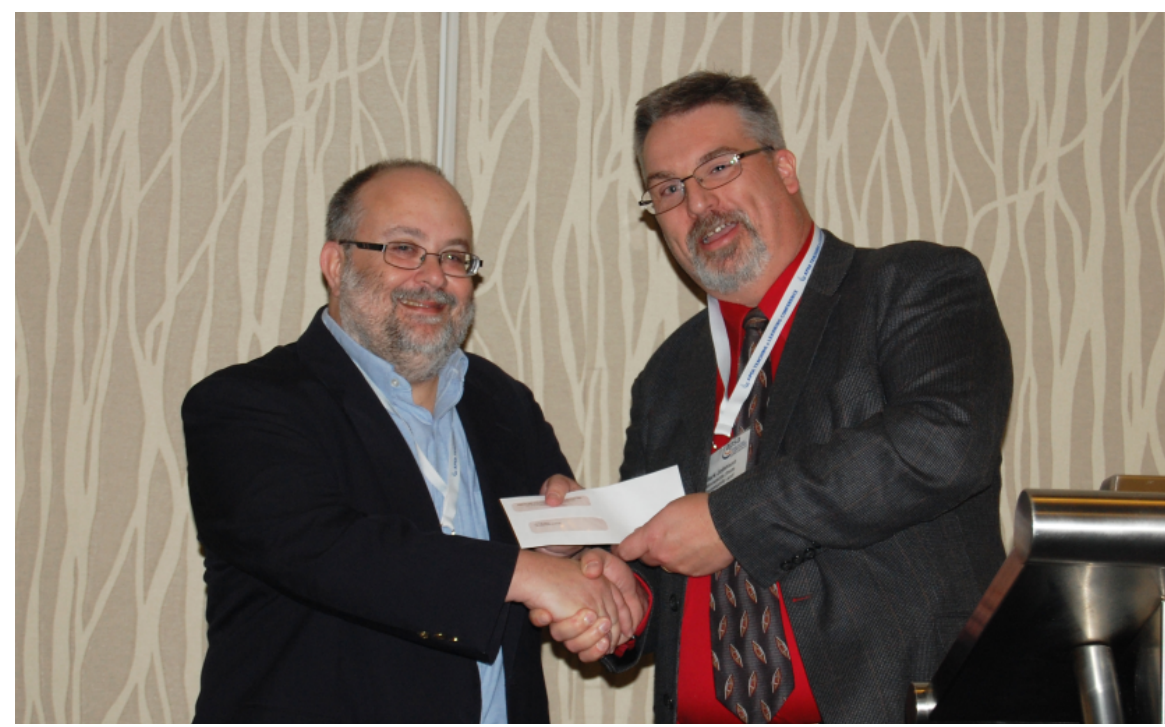

Mark Johnson, Minnesota State Community and Technical College, presents the CQ Press award to Victor Asal, SUNY, Albany .

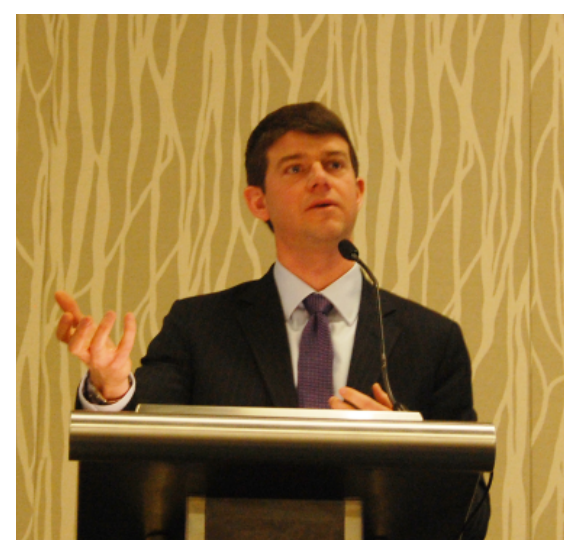

John M. Sides, George Washington University, delivers the Keynote Address at the 12th Annual APSA Teaching and Learning Conference.

for top consideration for this prize. He is a long-time member of APSA, a frequent participant and former track moderator of the APSA Teaching and Learning Conference, a widely published author advocating the innovative use of games in teaching, and an engaged mentor and collaborator in political science. He is the founder and contributing editor of the Active Learning in Political Science blog, an open resource for ideas on pedagogy in the field. He is well known for his innovative simulations and games such as "Classical Realism" simulation or "Hobbes Game," which are widely used in the classroom; his frequent peer-to-peer outreach efforts; and his service to the political science community. Asal's simulations challenge students to think critically and have made him one of the leading scholars on this topic. His nominator says it best: "He does not simply gift his innovations to his own students, nor does he simply share them with the wider academic world: he also encourages and supports innovation in others."

Looking ahead, the research presented and the ideas generated and shared at the

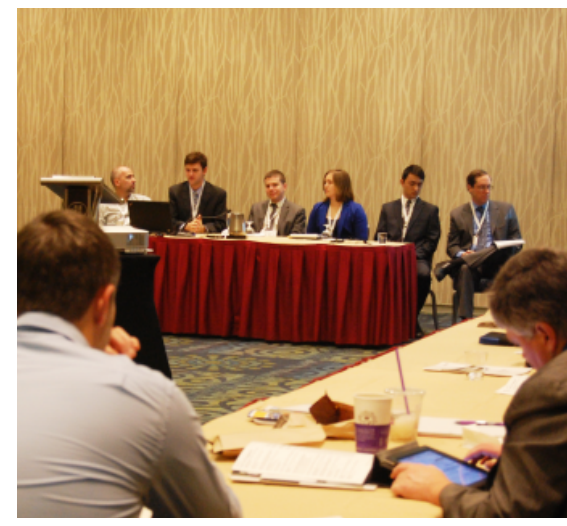

A group of scholars from George Washington University and National Defense University presents during a Saturday morning session in the Civic Engagement Track. 
2015 APSA Teaching and Learning Conference provide the unique opportunity to stimulate/create conversation in the discipline about pedagogical research and innovations.

Track summaries of the 2015 Teaching and Learning Conference will be published in the July 2015 issue of PS: Political Science and Politics. For more information on the 13th Annual Teaching and Learning Conference in 2016, visit http://www.apsanet.org/tlc.

\section{Teaching \& Learning Conference} Program Committee

Mark Johnson, Minnesota State Community and Technical College (chair)

Kimberley Cowell-Meyers, American University

Audrey Haynes, University of Georgia

Steven Rathgeb Smith, APSA

Cameron Thies, Arizona State University

Sherri Wallace, University of Louisville

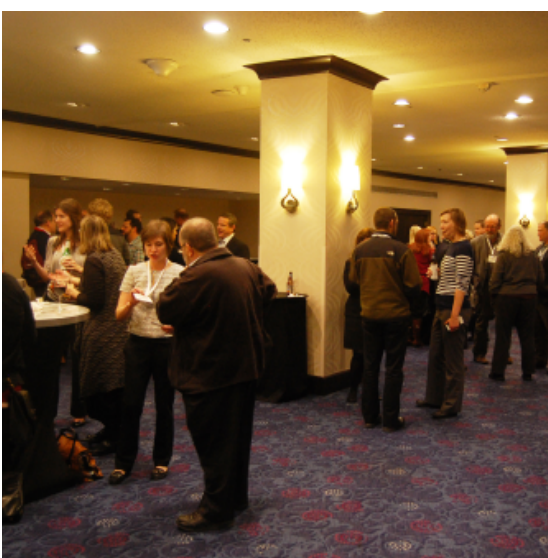

The opening reception was held at the Washington Hilton's International Terrace, where attendees were able to both greet old colleagues or make new aquaintances.

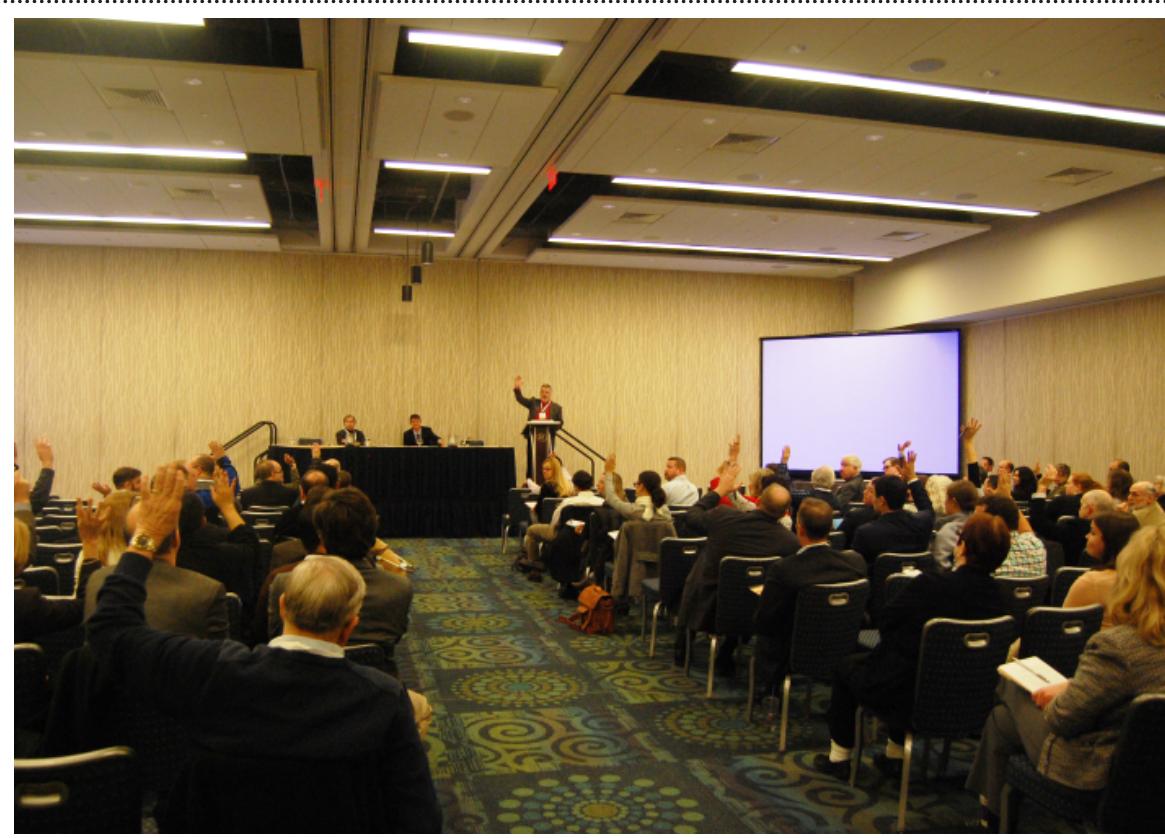

Conference Chair Mark Johnson greets attendees after the keynote address and asks for a show of hands from first time attendees. The conference was glad to welcome many scholars for the first time, and APSA looks forward to seeing many of these attendees again. (All pictures in spread courtesy of Drew Meadows)

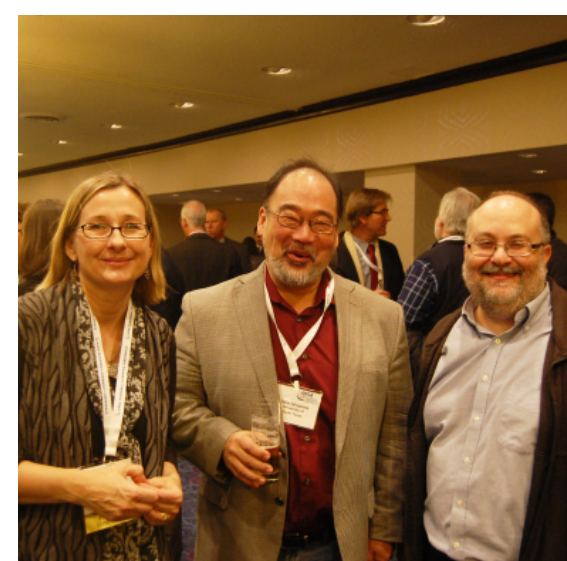

Attendees gather at the opening reception. Pictured left to right are Audrey Haynes, University of Georgia; John Ishiyama, University of North Texas; and Victor Asal, University at Albany, SUNY.

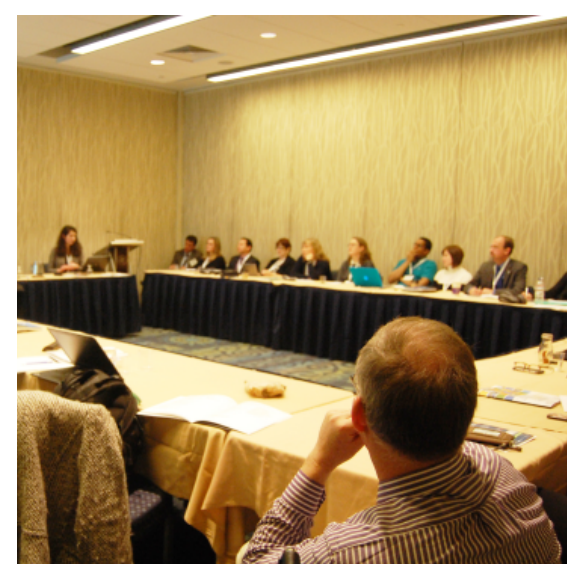

Ella Hamonic, Catholic University of Louvain, (far left) presents during a packed Saturday session in the Intergrating Technology in the Classroom Track. Sessions enjoyed good discussion feedback from attendees.

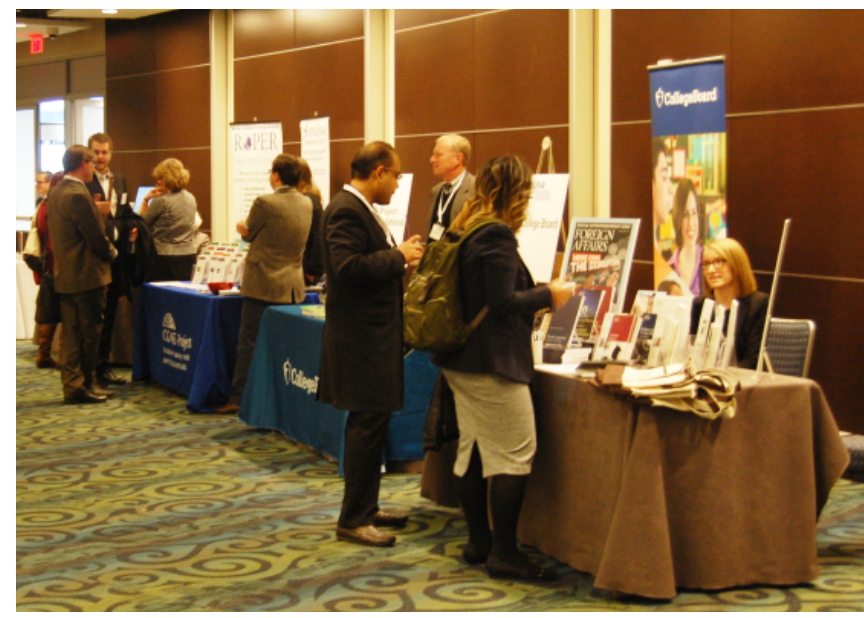

Attendees peruse the exhibit hall between sessions and connect with academic vendors about their resources. The exhibit hall provided a common gathering place for scholars.

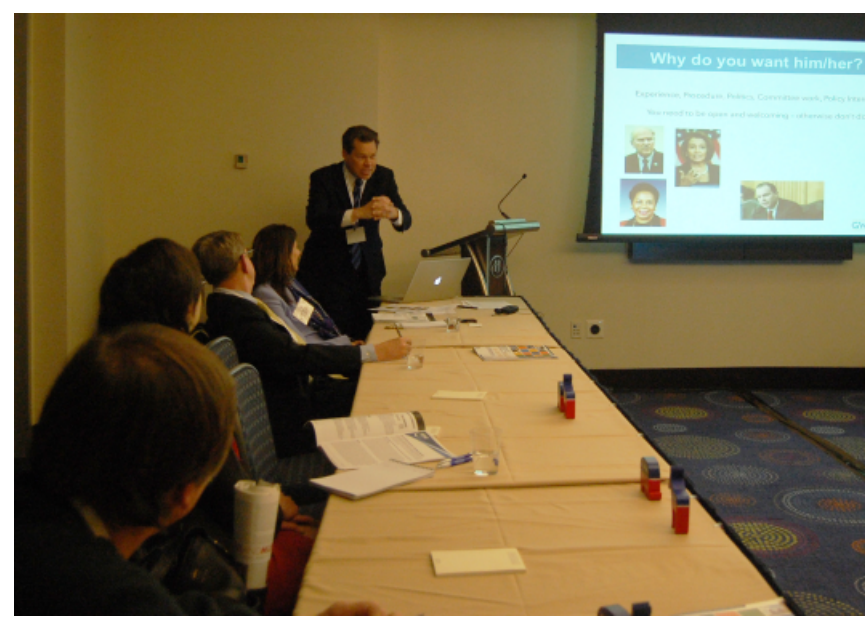

David Rehr, George Washington University, presents a short course on "Teaching Representation: Arranging a Congressional Member's Visit to the Classroom" on Friday afternoon. 